\title{
TOXICOLOGICAL SCREENING FOR POLYHERBAL COMBINATIONS OF MORINGA OLEIFERA AND EMBELIA RIBES IN EXPERIMENTAL ANIMALS.
}

\author{
RICHA SRIVASTAVA ${ }^{1}$, SAJAL SRIVASTAVA ${ }^{1 *}$, SATYA PRAKASH SINGH ${ }^{2}$ \\ ${ }^{1}$ Amity Institute of Pharmacy, Amity University Uttar Pradesh, Lucknow Campus 226 028, , India. ${ }^{2}$ Department of Pharmacy, \\ Integral University, Lucknow - 226 021, Uttar Pradesh, India. Email: ssrivastava2@lko.amity.edu
}

Received: 06 April 2018, Revised and Accepted: 18 May 2018

\section{ABSTRACT}

Objective: In the present study, aqueous ethanolic extract of Moringa oleifera and Embelia ribes was evaluated for the acute and subacute toxicity in combination. Despite the wide use of in folk medicine, no study has been published in the scientific literature about their in combination toxicological profile. In the acute toxicity test, oral administration of $2 \mathrm{~g} / \mathrm{kg}$ of combination produced neither mortality nor changes in behavior or any other physiological activities in mice.

Methods: The animals were observed for toxic symptoms continuously for the first $4 \mathrm{~h}$ after dosing. Finally, the number of survivors was noted after $24 \mathrm{~h}$, and these animals were then maintained for a further 13 days with observations made daily.

Result: In subacute toxicity studies, no mortality was observed when the two doses of 1 or $2 \mathrm{~g} / \mathrm{kg}$ day of $50 \%$ aqueous ethanolic extract in combination were administered for 28 days in mice. Hematological analysis showed no marked differences in any of the parameters examined in either the control or treated group of both sexes. The urinalysis was negative for glucose, ketogenic bodies, casts, red blood cells, and albumin in the control and treatment groups. There were no significant differences in the body and organ weights between control and treated animals of both sexes.

Conclusion: The combination was found safe in acute and subacute toxicities while chronic toxicity studies are further required for the support of the safe and sound use of this traditional plants.

Keywords: Moringa oleifera, Embelia ribes, Subacute, Herbal, Traditional.

(C) 2018 The Authors. Published by Innovare Academic Sciences Pvt Ltd. This is an open access article under the CC BY license (http://creativecommons. org/licenses/by/4. 0/) DOI: http://dx.doi.org/10.22159/ajpcr.2018.v11i7.26482

\section{INTRODUCTION}

The Moringa oleifera is the most widely cultivated species of a monogeneric own family, the Moringaceae; this is native to the Himalayan tracts of India, Pakistan, Afghanistan, and Bangladesh. This hastily-growing tree (also called the horseradish tree, mulangay, nébéday, saijhan, sajna, or Ben oil tree), became utilized by the historical Romans, Greeks, and Egyptians; it is now widely cultivated and has ended up naturalized in many locations inside the tropics [1]. It is perennial softwood tree with wooden of low fine, but which for hundreds of years has been advocated for traditional medicinal and commercial uses. It is already an essential crop in India, Ethiopia, the Philippines, and Sudan, and is being grown in West, East, and South Africa, tropical Asia, Latin America. All elements of the Moringa tree are fit for human consumption and have lengthy been ate up by humans. The other makes use of Moringa include: Alley cropping (biomass production), animal forage (leaves and treated seed-cake), biogas (from leaves), domestic cleaning agent (beaten leaves), blue dye (wood), fencing (residing trees), fertilizer (seed-cake), foliar nutrient (juice expressed from the leaves), green manure (from leaves), gum (from tree trunks), honey - and sugarcane juice - clarifier (powdered seeds), honey (flower nectar), medication (all plant components), decorative plantings, biopesticide (soil incorpomiceion ofleaves to prevent seedling damping off), pulp (wooden), rope (bark), tannin for tanning hides (bark and gum), and water purification (powdered seeds). Moringa seed oil (yield 30 -forty $\%$ through weight), additionally referred to as Ben oil, is candy non-sticking, non-drying oil that resists rancidity [2]. It has been used in salads, for excellent machine lubrication, and in the manufacture of perfume and hair care merchandise In the West, one of the pleasant recognized uses for Moringa is using powdered seeds to flocculate contaminants and purify drinking water but the seeds are also eaten green, roasted, powdered, and steeped for tea or used in curries. This tree has nowadays been endorsed as a first-rate indigenous supply of tremendously digestible protein, $\mathrm{Ca}, \mathrm{Fe}$, Vitamin $\mathrm{C}$, and carotenoids suitable for utilization in most of the so-referred to as "growing" regions of the sector in which under nourishment is a main problem $[3,4]$.

Embelia ribes additionally referred to as Vidanga is one of the oldest herbs in Indian traditional medication. E. ribes have a protracted history of use in ayurvedic gadget of medicine in the diverse bureaucracy such as churna, asava, aristha, lauha and taila. It is an Indo-Malaysian species, in particular, determined in India, Sri Lanka, Singapore, and Malaysia. In India, it's far majority found in important and lower Himalayas, Arunachal Pradesh, Assam, Bengal, Orissa, Andhra Pradesh, and Madhya Pradesh. It is available at some point of India as much as an altitude of $5000 \mathrm{ft}$ [5]. Vidanga is a struggling shrub, almost a climber. The roots are brownish gray, with bushy reddish roots. The stem is whitish gray, studded with lenticels with a mature girth of 45-72 cm. Leaves are coriaceous, elliptic, lanceolate 6-14 am lengthy and a couple of cm large, alternating, acuminate entire, flawlessly glabrous, and petiole 1-0.8 cm marginated. Flowers are pentamerous, minute, white or yellow [6]. Fruits are as small, i.e., 2-4 $\mathrm{mm}$ in size, ovate to subglobular tapped with fashion, clean, succulent, and in the dry condition with wrinkles with loss of calyx. The seeds are reddish in color but they come to be black as time passes. Seeds are enclosed in the brittle pericarp, included by means of the thin membrane and while that is taken off; the seeds are visibly included with a mild spot which disappears after immersion in water. The seeds are horny, depressed at the base and have ruminated endosperm. Taste is fragrant and astringent, with a slight pungency. The culmination, leaves, and roots are used for therapy various diseases. 


\section{METHODS}

\section{Plant material}

The M. oleifera (leaves) and E. ribes (burm fruit). The plant material was identified and authenticated taxonomically at State Ayurvedic College Lucknow. A voucher specimen (RS1 and RS3, respectively) of the collected sample was deposited in the institutional herbarium for future reference.

\section{Preparation of extracts}

The M. oleifera (leaves) and E. ribes (burm fruit) were washed with distilled water to remove dirt and soil, and shade dried. Routine pharmacognostic studies including organoleptic tests, macroscopic, and microscopic observations were carried out to confirm the identity of the materials. The dried materials were powdered and passed through a 10 -mesh sieve. The coarse powdered material $(500 \mathrm{~kg})$ was extracted thrice with ethanol $(50 \%, v / v)$. The extracts were filtered, pooled and concentrated at reduced temperature $\left(-5^{\circ} \mathrm{C}\right)$ on a rotary evaporator (IKA RV10) and then freeze-dried (Freezone ${ }^{\circledR} 4.5$, Labconco, USA $)$ at high vacuum $\left(133 \times 10^{-3} \mathrm{~m}\right.$ bar $)$ and at temperature $-40 \pm 2^{\circ} \mathrm{C}$ (yield $3.4 \%, w / w$ ). The extract was stored in the refrigerator and was suspended in double distilled water containing carboxymethyl cellulose $(1 \%, \mathrm{w} / \mathrm{v}, \mathrm{CMC})$ at the time of administration.

\section{Animals}

Swiss albino mice of either sex were kept in the departmental animal house in well cross ventilated room at $27 \pm 2^{\circ} \mathrm{C}$, and relative humidity 44-56\%, light and dark cycles of 10 and $14 \mathrm{~h}$, respectively, for 1 week before and during the experiments. Animals were provided with a standard rodent pellet diet (Amrut, India) and the feed was withdrawn 18-24 h before the experiment though, water was allowed ad libitum. All studies were conducted after obtaining prior approval from the Institutional Ethical Committee in accordance with the all experimental protocols were from the CPCSEA (AUUP/AIP/PhD/006/2017) and approved by Institutional Animal Ethics Committee.

\section{Acute toxicity}

The acute toxicity of the $50 \%$ aqueous ethanolic extract of $M$. oleifera (leaves) and E. ribes (burm fruit) was evaluated in mice using the up and down procedure (OECD, 2001b). Mice of either sex (three females and three males, weight: $25-35 \mathrm{~g}$, age: 6-8 weeks) received $M$. oleifera (leaves) and E. ribes (burm fruit) 50\% aqueous ethanolic extract starting at $2 \mathrm{~g} / \mathrm{kg}$ orally by gavage. The animals were observed for toxic symptoms continuously for the first $4 \mathrm{~h}$ after dosing. Finally, the number of survivors was noted after $24 \mathrm{~h}$ and these animals were then maintained for a further 13 days with observations made daily $[7,8]$.

\section{Subacute toxicity}

\section{Experimental animals}

Thirty mice (weight: 20-22 g; age: 6-8-week-old) were randomly assigned into three groups $(\mathrm{n}=10)$, five females and five males were housed in each group. Treatments were administered orally by oral gavage once a day for 4 weeks. The first group of mice, serving as a control, received $1 \% \mathrm{CMC}(5 \mathrm{ml} / \mathrm{kg})$; the second and third group received the $50 \%$ aqueous ethanolic extract of $M$. oleifera (leaves) and E. ribes (burm fruit) at doses of 1 and $2 \mathrm{~g} / \mathrm{kg}$, respectively. All animals were supplied with standard food and tap water ad libitum during the testing periods. All mice were observed daily for physiological and behavioral changes. Any mice that died during the test period were tested pathologically, and all animals were examined at the end of the test period.

\section{Observation and examination methods}

Clinical signs were observed at least once a day through the 28 days of dosing. Body weight, water and food intake and weight gain were measured once a week. Systolic blood pressure (SBP) and mean BP (MBP) were measured weekly in conscious, pre-warmed, restrained mice using tail-cuff BP recorder (UGO Basile, Model no 58500; ComerioVarese, Italy). Mice were acclimatized to heating chamber $\left(29-30^{\circ} \mathrm{C}\right)$ for 30 min before recording the BP (between 8:30 and 10:30 a.m.), to cause sufficient vasodilatation in the caudal artery. Three recordings were measured for each mice, and the average was calculated. Diastolic BP (DBP) was extrapolated from the SBP and MBP using the following formula: Where procured from the National Laboratory Animal Centre, Central Drug Research Institute, Lucknow, and India [9].

$$
\mathrm{DBP}=\frac{3 \mathrm{MBP}-\mathrm{SBP}}{2}
$$

Urine samples

On the day $27^{\text {th }}$, all the mice were placed in mice cages during $4-6 \mathrm{~h}$; $3-5 \mathrm{ml}$ of urine was collected for immediate urine analysis.

\section{Blood analysis}

On the day $29^{\text {th }}$, all surviving animals were fasted overnight and anesthetized afterward for blood collection from the right ventricle. Blood samples were collected into three tubes: (1) 3.2\% buffered sodium citrate tubes; (2) heparinized centrifuge tubes; and (3) dry nonheparinized centrifuge tubes. A blood analysis (hematology, coagulation, and chemistry) was carried out. The blood in the sodium citrate tubes was used for prothrombin time and partial thromboplastin time (PTT) estimation. The heparinized blood was used for a hematological study which included red blood cell (RBC) count, hemoglobin (Hb) concentration, hematocrit (Ht), mean corpuscular volume (MCV), MC hemoglobin (MCH), MCH concentration, platelets (Plt), white blood cell (WBC) count, and WBC differential count. The non-heparinized blood was allowed to coagulate before being centrifuged, and the serum separated [10]. The serum was assayed for glucose, creatinine, blood urea nitrogen, aspartate transaminase, alanine transaminase, potassium, sodium, chloride, calcium, phosphorus, conjugated bilirubin, total bilirubin, total cholesterol, high density lipoprotein, triglycerides, total protein, and albumin.

\section{Tissue analysis}

Vascular perfusion was performed for tissue fixation using isotonic saline $(250 \mathrm{ml})$ followed by $10 \%$ buffered formalin solution $(250 \mathrm{ml})$ without delay after collecting the blood samples. The organs of the body such as liver, brain, heart, spleen, kidneys, adrenals, epididymis, seminal vesicles, testes, and ovaries were detached and weighted immediately on an electronic balance for subsequent analysis. On the other hand intestines, eyes, thymus, uterus, prostate glands, and muscle with the sciatic nerve were also isolated for observation. Tissues from the control group and the group treated with the high dose of combination $(2 \mathrm{~g} / \mathrm{kg})$ were embedded in paraffin and subjected to hematoxylin-eosin staining. The pathological observations of all tissues were performed on gross and microscopic bases. When lesions were observed in the high dose group, the affected organs were also examined in the low dose group of combination $(1 \mathrm{~g} / \mathrm{kg})$.

\section{RESULTS}

\section{Acute toxicity}

Over the study period of 14 days, there were no deaths recorded in the male and female animals given $2 \mathrm{~g} / \mathrm{kg}$ of the $50 \%$ aqueous ethanolic extract of M. oleifera (leaves) and E. ribes (burm fruit) orally. During the observation period, animals did not produce any variations in the general appearance.

\section{Subacute toxicity}

\section{General signs}

During this study, no deaths were observed; no significant clinically relevant changes were observed in general behavior and other physiological activities in the present study.

\section{Body weight, $B P$, food, and water intake}

No changes were pragmatic in SBP or DBP (Table 1). No significant differences either in control or treated group of both sexes were noticed in various parameters such as MBP, body weight, food, and water intake. 
Urine analysis

The urinalysis in control and treated groups of both male and female mice were negative for glucose, ketonic bodies, casts, RBCs, and albumin although the volume was increased and the anti-diuretic activity was there.

\section{Hematological and plasma biochemical data}

No significant changes were observed in blood analysis of $\mathrm{Hb}, \mathrm{Ht}, \mathrm{RBCs}$, WBCs, and Plt in both groups and sexes compared to the control group. No difference observed between groups for leukocyte differential count; some parameters (Seg., MCV, MCH) were varied slightly found in some mice of the control and treatment groups (Table 2). There were no significant differences observed in any of the parameters examined in either the control or treated group of the male and female mice in the biochemical analysis (Table 3).

\section{Tissue analysis}

There were no significant differences between the control and treated groups in the organ weights of male and female mice (Table 4). Neither any abnormality was detectable in pathological examinations of the tissues; no was alterations noticed in the microscopic examination of the internal organs. The cellular appearances were unremarkable in both groups and sexes [11].

\section{DISCUSSION}

The acute toxicity study does now not display any toxic signs and symptoms, adjustments in conduct or mortality at $2 \mathrm{~g} / \mathrm{kg}$ doses. The subacute toxicity guiding principle implemented (OECD, 2001a) considers useless a full have a look at with three dose stages when at the least $1 \mathrm{~g} / \mathrm{kg}$-day does now not show toxicity effects, as was determined in the acute toxicity test. The high dose $M$. oleifera (leaves) and $E$. ribes (burm fruit) ( $2 \mathrm{~g} / \mathrm{kg}$ day) extracts combinations in the subacute examines turned into to be applied because human analysis suggests the use of an excessive dose level in accordance with the guideline (OECD, 2001a). A lower dose of $1 \mathrm{~g} / \mathrm{kg}$-day changed into used to determine dose associated toxic effects. In a subacute toxicity look at, it appeared that the $50 \%$ aqueous ethanolic extract of $M$. oleifera(leaves) and $E$. ribes (burm fruit) at the doses used did no longer produce any marked adjustments in both male and female mice, as evidenced by way of the absence of toxic symptoms, no modifications in water/food ingestion, or weight advantage. All animals survived till the scheduled euthanasia, and no gross pathological alteration turned into finding in the internal organs [12]. Organ weight found out that M. oleifera (leaves) and E. ribes (burm fruit) ( $2 \mathrm{~g} / \mathrm{kg}$ day), at the doses used did no longer produce organ swelling, atrophy, or hypertrophy. Moreover, the microscopic assessment did no longer discover any abnormalities in the $2 \mathrm{~g} / \mathrm{kg}$ M. oleifera (leaves) and E. ribes (burm fruit) ( $2 \mathrm{~g} / \mathrm{kg}$ day) combination when compared with the control group [13]. Microscopic assessment in the $1 \mathrm{~g} / \mathrm{kg}$ organization turned into no longer done in accordance with the subacute tenet (OECD, 2001a), that considers useless the microscopic exam of organs inside the low dose group when no histopathological abnormalities are determined in the high dose. The comparable biochemical results in the control group and $M$.

Table 1: Effect of 50\% aqueous ethanolic extract of M. oleifera (leaves) and E. ribes (burm fruit) on BPs in subacute toxicity

\begin{tabular}{|c|c|c|c|c|c|c|}
\hline \multirow[t]{2}{*}{ Week } & \multicolumn{2}{|c|}{ Control (1\% CMC) } & \multicolumn{4}{|c|}{ M. oleifera (leaves) and E. ribes (burm fruit) } \\
\hline & SBP & DBP & SBP & DBP & SBP & DBP \\
\hline \multicolumn{7}{|l|}{ Male } \\
\hline 0 & $118.33 \pm 3.81$ & $89.20 \pm 3.80$ & $121.31 \pm 3.27$ & $87.72 \pm 3.24$ & $121.1 \pm 3.94$ & $93.7 \pm 3.21$ \\
\hline 1 & $129.74 \pm 4.38$ & $87.81 \pm 4.55$ & $126.28 \pm 6.73$ & $79.23 \pm 4.58$ & $126.7 \pm 3.28$ & $94.7 \pm 3.35$ \\
\hline 2 & $136.72 \pm 3.85$ & $107.71 \pm 3.76$ & $148.76 \pm 8.94$ & $96.87 \pm 6.58$ & $126.9 \pm 4.18$ & $89.5 \pm 2.64$ \\
\hline 3 & $136.84 \pm 5.89$ & $97.93 \pm 9.87$ & $136.84 \pm 3.78$ & $96.85 \pm 3.84$ & $128.6 \pm 3.25$ & $96.2 \pm 5.37$ \\
\hline 4 & $128.81 \pm 2.28$ & $136.51 \pm 3.86$ & $134.70 \pm 4.42$ & $101.71 \pm 4.27$ & $128.5 \pm 5.34$ & $103.4 \pm 6.45$ \\
\hline \multicolumn{7}{|l|}{ Female } \\
\hline 0 & $125.33 \pm 3.51$ & $95.80 \pm 3.94$ & $130.46 \pm 2.39$ & $86.81 \pm 4.81$ & $120.8 \pm 3.45$ & $85.38 \pm 4.94$ \\
\hline 1 & $120.82 \pm 5.75$ & $86.84 \pm 4.51$ & $179.75 \pm 3.79$ & $86.53 \pm 3.78$ & $115.4 \pm 4.27$ & $82.13 \pm 4.61$ \\
\hline 2 & $116.84 \pm 6.24$ & $90.40 \pm 3.54$ & $121.63 \pm 4.51$ & $86.46 \pm 8.51$ & $107.7 \pm 6.07$ & $73.84 \pm 2.94$ \\
\hline 3 & $108.70 \pm 4.21$ & $84.10 \pm 4.21$ & $11.54 \pm 5.61$ & $7.14 \pm 6.41$ & $110.8 \pm 5.14$ & $75.32 \pm 5.38$ \\
\hline 4 & $105.50 \pm 6.24$ & $72.53 \pm 6.59$ & $102.21 \pm 5.67$ & $71.37 \pm 3.97$ & $104.3 \pm 4.34$ & $83.63 \pm 4.27$ \\
\hline
\end{tabular}

Data are expressed as mean SEM n=5, no statistical difference between control and test doses SBP: Systolic blood pressure and DBP: Diastolic blood pressure,

CMC: Carboxymethyl-cellulose, BPs: Blood pressures, SEM: Standard error of mean, M. oleifera: Moringa oleifera, E. ribes: Embelia ribes

Table 2: Effect of $50 \%$ aqueous ethanolic extract of M. oleifera (leaves) and E. ribes (burm fruit) on hematological values in subacute toxicity

\begin{tabular}{|c|c|c|c|c|c|c|}
\hline \multirow[t]{3}{*}{ Parameters } & \multicolumn{3}{|l|}{ Female } & \multicolumn{3}{|l|}{ Male } \\
\hline & \multirow{2}{*}{$\begin{array}{l}\text { Control } \\
(1 \% \mathrm{CMC})\end{array}$} & \multicolumn{2}{|c|}{$\begin{array}{l}\text { M. oleifera (leaves) and } E \text {. ribes } \\
\text { (burm fruit) (g/kg) }\end{array}$} & \multirow{2}{*}{$\begin{array}{l}\text { Control } \\
\text { (1\% CMC) }\end{array}$} & \multicolumn{2}{|c|}{$\begin{array}{l}\text { M. oleifera (leaves) and } E \text {. ribes } \\
\text { (burm fruit) (g/kg) }\end{array}$} \\
\hline & & 1 & 2 & & 1 & 2 \\
\hline $\mathrm{Hb}^{\mathrm{a}}$ & $15.00 \pm 0.50$ & $15.10 \pm 0.57$ & $15.60 \pm 0.39$ & $15.05 \pm 1.05$ & $17.57 \pm 0.95$ & $17.70 \pm 0.57$ \\
\hline $\mathrm{Ht}^{\mathrm{b}}$ & $57.50 \pm 1.71$ & $59.75 \pm 1.97$ & $57.73 \pm 1.37$ & $56.56 \pm 3.56$ & $53.66 \pm 1.65$ & $56.56 \pm 3.55$ \\
\hline $\mathrm{RBC}^{\mathrm{c}}$ & $06.63 \pm 0.63$ & $09.16 \pm 0.56$ & $06.90 \pm 0.60$ & $06.60 \pm 0.36$ & $09.36 \pm 0.51$ & $9.95 \pm 1.02$ \\
\hline Lymp. ${ }^{\mathrm{e}}$ & $62.60 \pm 1.65$ & $66.00 \pm 1.06$ & $72.00 \pm 2.67$ & $79.70 \pm 5.55$ & $76.75 \pm 2.52$ & $76.75 \pm 5.75$ \\
\hline Eosi. $^{\mathrm{f}}$ & $00.60 \pm 0.50$ & $01.00 \pm 0.51$ & $02.00 \pm 0.71$ & $00.70 \pm 0.27$ & $01.75 \pm 1.02$ & $0.25 \pm 0.25$ \\
\hline Mono.g & $02.50 \pm 1.17$ & $01.25 \pm 0.25$ & $02.25 \pm 1.02$ & $05.00 \pm 1.27$ & $02.24 \pm 1.22$ & $2.00 \pm 0.71$ \\
\hline PLT. & $912.70 \pm 96.27$ & $1242.00 \pm 62.74$ & $1007.21 \pm 92.40$ & $906.27 \pm 101.22$ & $924.26 \pm 104.74$ & $1077.27 \pm 27.27$ \\
\hline $\mathrm{MCV}^{\mathrm{i}}$ & $44.60 \pm 2.66$ & $44.40 \pm 0.77$ & $62.40 \pm 2.27$ & $44.20 \pm 1.24$ & $47.00 \pm 2.27$ & $44.00 \pm 1.22$ \\
\hline $\mathrm{MCH}^{\mathrm{j}}$ & $17.26 \pm 0.97$ & $16.47 \pm 0.21$ & $19.27 \pm 1.22$ & $16.74 \pm 0.47$ & $17.47 \pm 0.42$ & $17.10 \pm 0.97$ \\
\hline $\mathrm{MCHC}^{\mathrm{k}}$ & $21.02 \pm 0.20$ & $20.22 \pm 0.27$ & $20.74 \pm 0.40$ & $20.52 \pm 0.27$ & $20.02 \pm 0.22$ & $27.67 \pm 0.62$ \\
\hline Seg. ${ }^{1}$ & $12.70 \pm 0.72$ & $12.00 \pm 0.72$ & $15.00 \pm 2.52$ & $12.20 \pm 6.59$ & $17.25 \pm 2.66$ & $21.50 \pm 5.57$ \\
\hline
\end{tabular}

Data are expressed as mean \pm S.E.M., $\mathrm{n}=5$. No statistical difference between control and M. oleifera (leaves) and E. ribes (burm fruit) (p $>0.05$ ). ${ }^{\text {Hemoglobin }}$ concentration (g/dl). ${ }^{b}$ Hematocrit (\%), ${ }^{\mathrm{c}}$ red blood cell $\left(\times 10^{6} \mathrm{~mm}^{-3}\right),{ }^{\mathrm{d}}$ white blood cell $\left(\times 10^{3} \mathrm{~mm}^{-3}\right)$, ${ }^{\text {elymphocyte }}(\%) .{ }^{\mathrm{f}}$ Eosinophilic leukocyte $(\%)$, ${ }^{\mathrm{g}} \mathrm{monocyte}(\%)$,

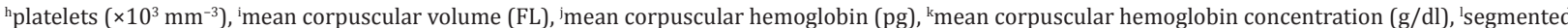
leukocyte (\%). CMC: Carboxymethyl-cellulose, SEM: Standard error of mean, M. oleifera: Moringa oleifera, E. ribes: Embelia ribes 
Table 3: Effect of 50\% aqueous ethanolic extract of M. oleifera (leaves) and E. ribes (burm fruit) on blood chemistry values in subacute toxicity

\begin{tabular}{|c|c|c|c|c|c|c|}
\hline \multirow[t]{3}{*}{ Parameters } & \multicolumn{3}{|l|}{ Female } & \multicolumn{3}{|l|}{ Male } \\
\hline & \multirow{2}{*}{$\begin{array}{l}\text { Control } \\
\text { (2\% CMC) }\end{array}$} & \multicolumn{2}{|c|}{$\begin{array}{l}\text { M. oleifera (leaves) and E. ribes } \\
\text { (burm fruit) (g/kg) }\end{array}$} & \multirow{2}{*}{$\begin{array}{l}\text { Control } \\
(2 \% \mathrm{CMC}) \\
\end{array}$} & \multicolumn{2}{|c|}{$\begin{array}{l}\text { M. oleifera (leaves) and E. ribes } \\
\text { (burm fruit) (g/kg) }\end{array}$} \\
\hline & & 2 & 2 & & 2 & 2 \\
\hline $\mathrm{TB}^{\mathrm{a}}$ & $00.2 \pm 0.028$ & $0.27 \pm 0.06$ & $0.20 \pm 0.022$ & $0.28 \pm 0.022$ & $0.25 \pm 0.022$ & $0.22 \pm 0.028$ \\
\hline $\mathrm{CB}^{\mathrm{b}}$ & $0.026 \pm 0.005$ & $0.062 \pm 0.002$ & $0.066 \pm 0.006$ & $0.027 \pm 0.005$ & $0.029 \pm 0.007$ & $0.059 \pm 0.008$ \\
\hline $\mathrm{AST}^{\mathrm{c}}$ & $259.22 \pm 06.69$ & $222.6 \pm 22.08$ & $202.2 \pm 67.00$ & $265.2 \pm 28.52$ & $225.2 \pm 6.25$ & $229.0 \pm 26.22$ \\
\hline Total proteins (g/dl) & $07.52 \pm 00.25$ & $7.02 \pm 0.07$ & $07.86 \pm 00.09$ & $07.20 \pm 00.25$ & $7.76 \pm 0.26$ & $7.86 \pm 0.27$ \\
\hline Albumin $(\mathrm{g} / \mathrm{dl})$ & $02.76 \pm 00.09$ & $02.92 \pm 0.08$ & $02.00 \pm 00.2$ & $02.22 \pm 00.25$ & $2.65 \pm 0.05$ & $2.80 \pm 0.22$ \\
\hline $\mathrm{BUN}^{\mathrm{e}}$ & $29.90 \pm 2.78$ & $27.00 \pm 02.22$ & $22.26 \pm 02.00$ & $20.20 \pm 02.28$ & $22.20 \pm 2.22$ & $20.60 \pm 2.02$ \\
\hline Creatinine $(\mathrm{mg} / \mathrm{dl})$ & $00.87 \pm 0.06$ & $00.96 \pm 0.02$ & $00.98 \pm 0.02$ & $0.92 \pm 00.06$ & $0.92 \pm 0.02$ & $0.89 \pm 0.02$ \\
\hline $\mathrm{HDL}^{\mathrm{f}}$ & $29.00 \pm 02.68$ & $60.80 \pm 02.26$ & $27.00 \pm 02.95$ & $26.00 \pm 02.07$ & $27.67 \pm 2.87$ & $60.20 \pm 2.69$ \\
\hline Cholesterol (mg/dl) & $56.60 \pm 07.56$ & $57.60 \pm 02.29$ & $68.20 \pm 02.65$ & $52.80 \pm 02.87$ & $52.80 \pm 6.72$ & $55.80 \pm 2.99$ \\
\hline $\mathrm{TG}^{\mathrm{g}}$ & $67.60 \pm 20.22$ & $26.20 \pm 02.66$ & $22.60 \pm 06.82$ & $60.80 \pm 22.70$ & $25.20 \pm 8.00$ & $22.20 \pm 0.66$ \\
\hline Potassium (meq./L) & $05.78 \pm 00.25$ & $05.98 \pm 00.26$ & $06.20 \pm 00.20$ & $05.86 \pm 00.26$ & $5.26 \pm 0.25$ & $6.00 \pm 0.22$ \\
\hline Chloride (meq./l) & $202.07 \pm 02.62$ & $95.60 \pm 02.22$ & $98.60 \pm 00.75$ & $92.60 \pm 02.52$ & $99.20 \pm 2.02$ & $97.60 \pm 2.27$ \\
\hline Calcium (mg/dl) & $9.96 \pm 00.29$ & $20.22 \pm 00.27$ & $20.62 \pm 00.67$ & $09.70 \pm 00.22$ & $0.27 \pm 0.26$ & $9.92 \pm 0.22$ \\
\hline Phosphorus (mg/dl) & $07.76 \pm 00.26$ & $08.06 \pm 00.60$ & $08.58 \pm 00.88$ & $08.26 \pm 00.62$ & $7.06 \pm 0.56$ & $8.78 \pm 0.60$ \\
\hline $\mathrm{PT}^{\mathrm{h}}$ & $22.70 \pm 00.87$ & $20.90 \pm 02.92$ & $26.90 \pm 02.25$ & $09.98 \pm 00.72$ & $26.22 \pm 6.20$ & $22.22 \pm 2.20$ \\
\hline $\mathrm{PTT}^{\mathrm{i}}$ & $26.20 \pm 02.52$ & $27.20 \pm 06.76$ & $62.55 \pm 08.26$ & $22.50 \pm 02.72$ & $26.67 \pm 9.02$ & $22.20 \pm 6.62$ \\
\hline Glucose (mg/dl) & $229.60 \pm 26.80$ & $262.60 \pm 26.70$ & $298.6 \pm 22.80$ & $222.6 \pm 22.82$ & $226.82 \pm 20.80$ & $276.6 \pm 22.0$ \\
\hline
\end{tabular}

Data are expressed as mean SEM, $\mathrm{n}=5$. No statistical difference between control and M. oleifera (leaves) and E. ribes (burm fruit) (g/kg) ( $>0.05$ ). ${ }^{a}$ Total

bilirrubin (mg/dl), bdirect bilirrubin (mg/dl), caspartate transaminase (U/l), ${ }^{\mathrm{d} A l a n i n e}$ transaminase (U/l), e blood urea nitrogen (mg/dl), ' high-density lipoproteins (mg/

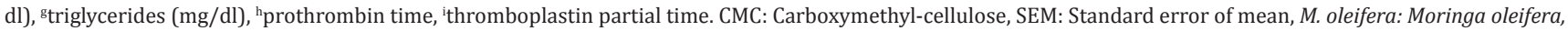
E. ribes: Embelia ribes

Table 4: Effect of $50 \%$ aqueous ethanolic extract of M. oleifera (leaves) and E. ribes (burm fruit) on organ weights (g) in rats in subacute toxicity

\begin{tabular}{|c|c|c|c|c|c|c|}
\hline \multirow[t]{3}{*}{ Organs } & \multicolumn{3}{|l|}{ Female } & \multicolumn{3}{|l|}{ Male } \\
\hline & \multirow{2}{*}{$\begin{array}{l}\text { Control } \\
(1 \% \mathrm{CMC})\end{array}$} & \multicolumn{2}{|c|}{$\begin{array}{l}\text { M. oleifera (leaves) and } E \text {. ribes } \\
\text { (burm fruit) (g/kg) }\end{array}$} & \multirow{2}{*}{$\begin{array}{l}\text { Control } \\
(1 \% \mathrm{CMC}) \\
\end{array}$} & \multicolumn{2}{|c|}{$\begin{array}{l}\text { M. oleifera (leaves) and E. ribes } \\
\text { (burm fruit) (g/kg) }\end{array}$} \\
\hline & & 1 & 2 & & 1 & 2 \\
\hline Brain & $1.98 \pm 0.09$ & $1.49 \pm 0.14$ & $1.25 \pm 0.10$ & $1.67 \pm 0.09$ & $1.55 \pm 0.11$ & $1.96 \pm 0.05$ \\
\hline Heart & $0.72 \pm 0.04$ & $0.69 \pm 0.02$ & $0.57 \pm 0.04$ & $0.82 \pm 0.21$ & $0.92 \pm 0.02$ & $0.87 \pm 0.04$ \\
\hline Adrenal & $0.19 \pm 0.03$ & $0.14 \pm 0.02$ & $0.48 \pm 0.25$ & $0.35 \pm 0.05$ & $0.23 \pm 0.02$ & $0.36 \pm 0.02$ \\
\hline Spleen & $0.45 \pm 0.05$ & $0.58 \pm 0.04$ & $0.79 \pm 0.02$ & $0.67 \pm 0.08$ & $0.72 \pm 0.04$ & $0.57 \pm 0.04$ \\
\hline Kidneys & $1.92 \pm 0.14$ & $1.68 \pm 0.10$ & $1.81 \pm 0.12$ & $2.24 \pm 0.17$ & $1.16 \pm 0.18$ & $2.12 \pm 0.19$ \\
\hline Stomach & $1.79 \pm 0.04$ & $1.96 \pm 0.05$ & $1.54 \pm 0.08$ & $2.07 \pm 0.15$ & $3.12 \pm 0.14$ & $2.89 \pm 0.13$ \\
\hline Pancreas & $1.42 \pm 0.07$ & $1.34 \pm 0.08$ & $1.72 \pm 0.14$ & $1.33 \pm 0.08$ & $1.58 \pm 0.14$ & $1.03 \pm 0.15$ \\
\hline Testis & - & - & - & $3.17 \pm 0.04$ & $4.25 \pm 0.06$ & $2.81 \pm 0.07$ \\
\hline Ovaries & $0.30 \pm 0.01$ & $0.24 \pm 0.01$ & $0.18 \pm 0.01$ & - & - & - \\
\hline
\end{tabular}

Data are expressed as mean SEM, $\mathrm{n}=5$. No statistical difference between control and M. oleifera (leaves) and E. ribes (burm fruit) (p > 0.05). SV and Epi: Seminal vesicles and epididymis. CMC: Carboxymethyl-cellulose, SEM: Standard error of mean, M. oleifera: Moringa oleifera, E. ribes: Embelia ribes

oleifera (leaves) and E. ribes (burm fruit) $(2 \mathrm{~g} / \mathrm{kg}$ day) treated groups were consistent with the morphological analysis when compared. It has been considered and documented as a potent. However, no serum potassium abnormalities have been located within the subacute toxicity study, a finding probable related to proximal tubular hypertrophy; a commonplace diuretic tolerance mechanism taking location after continual dosing and no longer with unmarried dose administration as was the case of the diuretic take a look at. These types of herbal drug interactions had been already described with different medicinal plant life. SBP and DBP had been now not altered by the administration of combination. The impact studied on small intestine, spleen, kidney, heart in situ, carotid blood stress and aorta, and other muscle mass as uterus and bladder movement The failure of the $50 \%$ aqueous ethanolic extract in aggregate to lower the BP on this observe might be explained through renal and autonomic homeostatic mechanisms in normotensive animals which are able to compensating a pharmacological discount in BP. These mechanisms include an increase in sodium reabsorption in the proximal tubule a lower inside the production of nitric oxide and an increase in manufacturing of the neurohumoral mediator's adrenaline and angiotensin II. As opposed to normotensive animals, some of these homeostatic mechanisms are absent in maximum animal fashions of high BP, permitting the discount of blood stress by means of a selected 
pharmacological manipulation. In short, the 50\% aqueous ethanolic extract of the mixture was found to be safe in acute and subacute toxicities in experimental animals. Chronic toxicity, mutagenicity, and carcinogenicity research are in addition necessary to help the safe and sound use of this combination in future.

\section{ACKNOWLEDGMENT}

We acknowledge that all the studies related to this project are done in Amity Institute of pharmacy, Amity University Uttar Pradesh, Lucknow Campus 226028.

\section{AUTHORS CONTRIBUTIONS}

Richa Srivastava: Literature search, study design, experimental work, data collection, data interpretation writing. Dr. Sajal Srivastava: Data interpretation, review of the manuscript, data analysis. Dr. S. P. Singh: Proof reading of manuscript and data analysis.

\section{CONFLICTS OF INTEREST}

There were no conflicts of interest among the authors.

\section{REFERENCES}

1. Ruckmani K, Kavimani S, Anandan R, Jaykar B. Effect of Moringa oleifera Lam on paracetamol induced hepatoxicity. Indian J Pharm Sci 1998;60:33-5.

2. Rebecca HS, Sharon M, Arbainsyah A, Lucienne D. Moringa oleifera: Medicinal and Socio-Economic uses. International Course on Economic Botany. Netherlands: National Herbarium Leiden; 2006. 2-6.
3. Mehta K, Balaraman R, Amin AH, Bafna PA, Gulati OD. Effect of fruits of moringa oleifera on the lipid profile of normal and hypercholesterolaemic rabbits. J Ethnopharmacol 2003;86:191-5.

4. Nickon F, Saud ZA, Rehman MH, Haque ME. In vitro antimicrobial activity of the compound iso-lated from chloroform extract of M. oleifera Lam. Pak J Biol Sci 2003;22:1888-90.

5. Prakash AO. Short term toxicity of Embelin in female rats. Phytother Res 1994;8:257-64.

6. Pande VV, Baheti KG, Chandorkar JG, Tenpe CR, Sonal D. A comparative study of aqueous extract of Tinospora cordifolia, Cyperus rotundus and Embelia ribes on hyperlipidaemia induced albino rats. Biomedical 2006;1:264-6.

7. OECD (The Organization of Economic Co-operation Development), The OECD Guideline for Testing of Chemical: 407 Repeated Dose Oral Toxicity-Rodent: 28-Day or 14-Day Study. Paris: OECD; 2001a. 1-7.

8. OECD (The Organization of Economic Co-operation Development), The OECD Guideline for Testing of Chemical: 420 Acute Oral Toxicity. Paris: OECD; 2001b. p. 1-14.

9. Amresh G, Singh PN, Rao CV. Toxicological screening of traditional medicine Laghupatha (Cissampelos pareira) in experimental animals. J Ethnopharmacol 2008;116:454-60.

10. Amresh G, Kant R, Zeashan H, Gupta RJ, Ch VR, Singh PN. Gastroprotective effects of ethanolic extract from Cissampelos pareira in experimental animals. J Natl Med 2007b;61:323-8.

11. Elham AE, Mahmoud EM, Maha FM. Acute toxicity of different sizes of silver nanoparticles intraperitonally injected in balb/c mice using two toxicological methods. Int J Pharm Pharm Sci 2014;7:94-9.

12. Chan K. Some aspects of toxic contaminants in herbal medicines. Chemosphere 2003;52:1361-71.

13. Belhekar SN, Chaudhari PD. Acute and sub-acute oral toxicity assessment of the polyherbal formulation in albino wister rats. Int $\mathrm{J}$ Pharm Pharm Sci 2016;8:311-6. 